\title{
SOVELTUUKO TUTKIVAN OPPIMISEN TEORIA AMMATTIKORKEAKOULUOPETUKSEN KÄYTÄNTÖÖN?
}

Kirjoittajien tavoitteena oli selvittää, miten tutkivan oppimisen malli soveltuu ammattikorkeakouluopetukseen, erityisesti liiketalouden koulutusohjelman kansainvälisiin kehittämishankkeisiin. Kävi ilmi, että käytännön toiminta on paljon monimutkaisempaa ja vaativampaa kuin pelkän teoreettisen mallin perusteella voisi päätellä. Artikkeli käsittelee teoreettisen mallin ja käytännön välisiä eroja sekä antaa kehittämisehdotuksia tutkivan oppisen mallin soveltamiseksi ammattikorkeakouluopetukseen. Malli todettiin kehiteltynä käyttökelpoiseksi.

\section{SEPPO KINKKI JA ANITA LEHTINEN-TOIVOLA}

A mmattikorkeakoulusta valmistuvat opiskelijat tarvitsevat monia erilaisia taitoja selviytyäkseen työelämän lisääntyvistä vaatimuksista. Koulun ja opetusjärjestelmän on löydettävä uusia pedagogisia menettelytapoja ja käytäntöjä, jotta tietoyhteiskunnan asettamiin haasteisiin voitaisiin vastata (Hakkarainen \& Lonka \& Lipponen 2004). Erilaisissa työelämälähtöisissä hankkeissa pyritäänkin lähentämään opetusta ja työelämän ammattikäytäntöjä toisiinsa.

Ammattikorkeakoululaki (9.5.2003/351, 4§ ja $5 \S)$ määrittelee ammattikorkeakoulun tehtäväksi harjoittaa ammattikorkeakouluopetusta palvelevaa sekä työelämää ja aluekehitystä tukevaa ja alueen elinkeinorakenteen huomioon ottavaa soveltavaa tutkimus- ja kehitystyötä. Ammattikorkeakoulun tulee tehtäviään suorittaessaan olla erityisesti omalla alueellaan yhteistyössä elinkeino- ja muun työelämän sekä suomalaisten ja ulkomaisten korkeakoulujen samoin kuin muiden oppilaitosten kanssa. Laki ei sinällään ota kantaa tutkimuksen tekemisen pedagogisiin tavoitteisiin.

Jatkamme artikkelissamme Vartiaisen (2000) herättämää keskustelua tutkivan oppimisen soveltuvuudesta työelämän tarpeisiin. Siinä työelämällä tarkoitetaan voittoa tavoittelevia yrityksiä. Vartiaisen mukaan Hakkarainen \& Lonka \& Lipposen (1999) esittämän lähestymistavan rajoituksena on, että oppimista synnyttävät ongelmat nähdään pääosin tiedollisina ongelmina oppilaitosympäristössä. Hakkarainen ym.(2004) toteavatkin, että tutkivan oppimisen mallissa oppimisen tiedollinen ulottuvuus on alun perin painottunut liikaa.

Vartiaisen mukaan oppilaitosympäristö on usein käytännöstä vieraantunut paikka, koska työelämäympäristössä ongelmat ovat läsnä koko ajan sulautuneina käytännön toimintaan. (Vartiainen 2000, 160). Vartiaisen mielestä tutkivassa oppimisessa oppiminen tapahtuu ehkä hieman irrallaan käytännön toiminnasta, omassa rationaalisessa reflektoinnin kehässään. Ideaalista olisi oppimisen, toiminnan ja sen käsitteellistämisen yhdistäminen toisiinsa. Tämä jo siksi, että työelämän haasteet turbulenteissa ympäristöissä eivät anna mahdollisuuksia erillisiin oppimistilanteisiin (Vartiainen 2000, 161). Ehkä tästä syystä tämän tyyppistä oppimista on tutkittu kovin vähän (Poikela 2003, 136). Hakkarainen \& Lonka \& Lipponen (2004) painottavat, että käsitteellisen ja käytännöllisen työskentelyn välisen tasapainon löytäminen on merkittävä tutkivan oppimisen soveltamisen haaste.

Tarkastelemme, soveltuuko tutkivan oppimisen teoria (Hakkarainen \& Lonka \& Lipponen, 2004) ammattikorkeakouluopetuksen käytäntöön. Tarkastelu perustuu yrityksille toteutettuihin kansainvälisiin kehittämishankkeisiin liiketalouden 
koulutusohjelmassa. Tavoitteena ei ole selvittää kansainvälisyyden merkitystä tutkivassa oppimisessa, vaikkakin se on keskeinen tekijä oppimisprosessissa.

Kehittämishankkeissa etsittiin vastauksia kysymyksiin:

1) Vastaavatko tutkivan oppimisen ja ammattikorkeakouluopetuksessa liiketalouden koulutusohjelmassa yrityksille toteutettujen kansainvälisten kehittämishankkeiden prosessien vaiheet ja keskeiset osatekijät toisiaan?

2) Miltä osin prosessien lähtökohtaolettamukset ja reunaehdot mahdollisesti eroavat toisistaan?

Hankkeista kävi ilmi, että (kysymys 1) kyseinen malli tarjoaa hyvän pohjan asian tarkastelulle. Keskeisin ero syntyy siitä, että käytännön toiminta on paljon monimutkaisempaa ja vaativampaa kuin pelkän teoreettisen mallin perusteella voisi päätellä. Kysymyksen 2 osalta voidaan todeta, että prosessien (mallien) lähtökohtaolettamukset ja reunaehdot eroavat toisistaan. Eroja tuovat muun muassa maksavan toimeksiantajan asettamat laatuvaatimukset, kokonaisvaltaisen hankkeen vaatimat integroidut osaamistarpeet, rajallinen ajankäyttö sekä vaatimus hankeryhmän itseohjautuvuudesta.

Artikkeli sisältää ennemminkin näkökulmia käytäntöön, olkoonkin, että se antaa myös kehittämisehdotuksen tutkivan oppimisen mallin (Hakkarainen ym. 2004) soveltamiseksi ammattikorkeakouluopetuksessa liiketalouden koulutusohjelmassa yrityksille toteutettuihin kansainvälisiin kehittämishankkeisiin.

\section{TUTKIVA OPPIMINEN KANSAINVÄLISESSÄ KEHITTÄMISHANKKEESSA}

Monet tutkijat (mm.Castells 1996, Stehr 1994) ovat ilmaisseet työelämän ammattilaisiin kohdistuvan yhä enemmän vaatimuksia. Kansainvälistyminen, tietointensiivisen työmäärän ja informaatioteknologian käytön kasvu ja uudenlaiset työskentelytavat lisäävät osaamisvaatimuksia eri ammateissa. Informaatioyhteiskunnassa kohdattavat ongelmat ovat yleensä kompleksisia. Tämä edellyttää ongelmanratkaisutaitoja tilanteissa, joissa selvää ratkaisua ei ole nähtävissä.

Haasteena näyttäisi olevan, että koulutukselliset järjestelmät eivät kykene tarjoamaan opiskelijoille malleja tai informaatiota, jolla nämä ongel- mat voitaisiin ratkaista. Opetuksen tulisi enemmän harjoituttaa opiskelijoiden ongelmanratkaisukykyä (Hakkarainen ym.).

Tutkivan oppimisen kanssa samansuuntaisia oppimisja työskentelymuotoja ovat kokemuksellinen oppiminen (Kolb 1984), kontekstuaalinen oppiminen (Eteläpelto \& Rasku-Puttonen 1999), ongelmaperustainen oppiminen (Poikela \& Poikela 2000) ja projektioppiminen. (Vesterinen 2003).- Rajatusta tavoitteenasettelusta johtuen mallien välisiä yhtymäkohtia ei tässä yhteydessä tarkemmin analysoida.

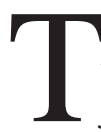

utkivan oppimisen lähtökohtana on ajatus, jonka mukaan oppiminen on parhaimmillaan tutkimusprosessi, joka synnyttää sekä uutta ymmärrystä että uutta tietoa. Olennaista tutkivassa oppimisessa on tie-

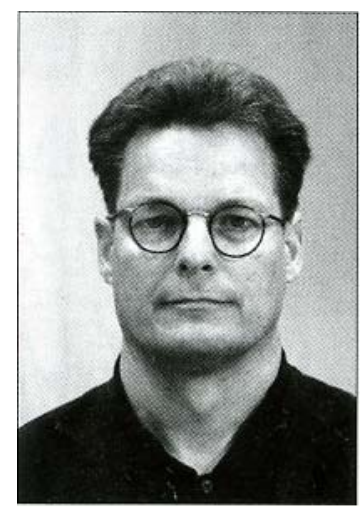

Seppo Kinkki

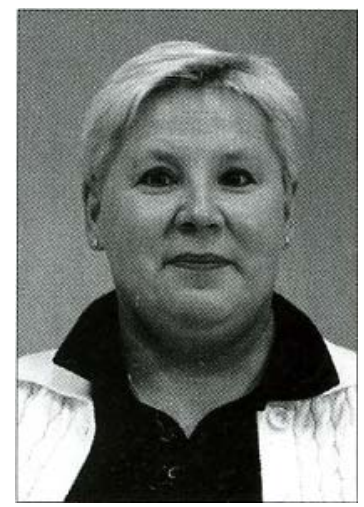

Anita Lehtinen-Toivola don käsittely toiminnan kohteena. Kun osanottajat ponnistelevat yhteisen tietämyksen edistämiseksi, samalla heidän oma ajattelunsa, ymmärryksensä ja tietämyksensä kehittyvät. (Hakkarainen ym. 2004) Tämä koskee sekä opiskelijoita, opettajia että työelämän edustajia. Käsityksemme mukaan Hakkarainen ym. (2004) tutkivan oppimisen malli soveltuu hyvin testattavaksi ammattikorkeakouluopetuksessa.

Kuviossa 1 esitetään malli tutkivan oppimisen prosessista ja sen keskeisistä osatekijöistä Hakkainen ym. (2004) mukaan. Uudesta työskentelyteoriasta ei johda nuoli Jaettuun asiantuntijuuteen, vaan siitä alkaa uusi prosessi.

Tutkivan oppimisen prosessissa ovat seuraavat osatekijät:

a) Kontekstin luominen ja opetuksen ankkurointi. Ongelmat ankkuroidaan opiskelijoiden aikaisempiin kokemuksiin ja tietoihin. Ankkuroimista tapahtuu koko oppimisprosessin ajan. Oppimisprosessin kohteen tulisi liittyä opiskelijoiden käsitteellisen ympäristön kannalta keskeiseen aihepiiriin. Sen tulisi olla riittävän moniulotteinen 


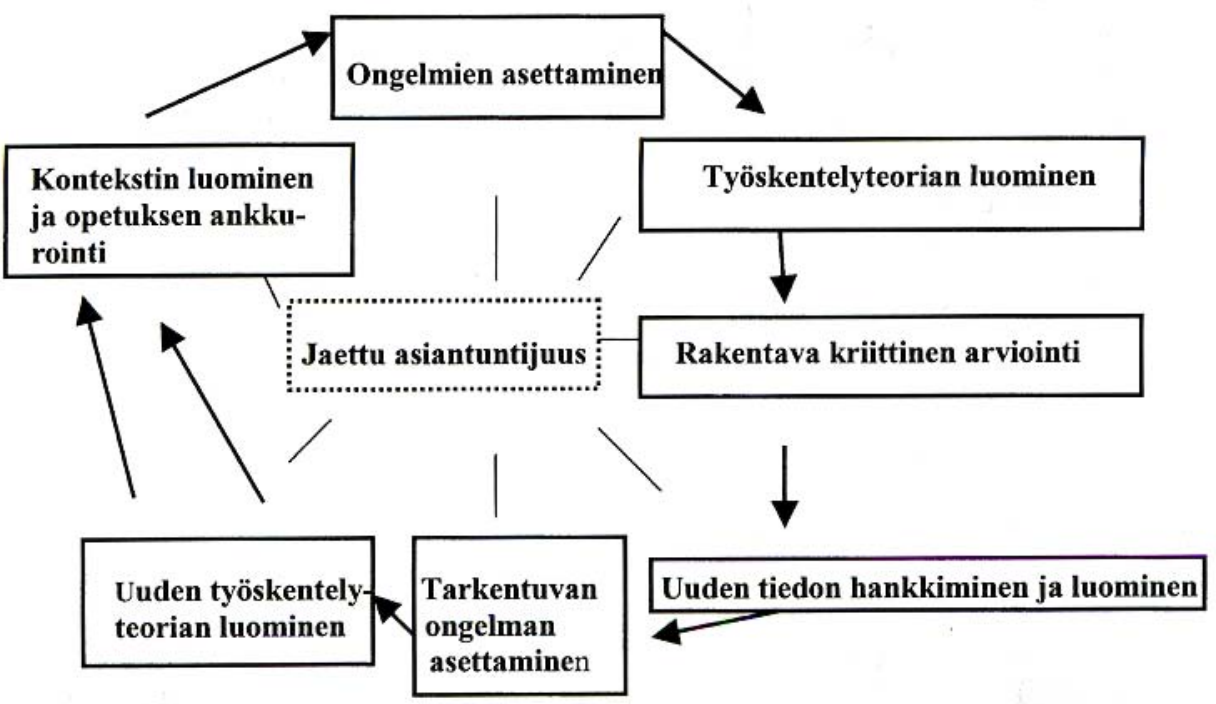

\section{KUVIO 1. TUTKIVAN OPPIMISEN PROSESSI JA SEN KESKEISET OSATEKIJÄT (HAKKARAINEN-)}

ja haastava tarjotakseen mahdollisuuden erilaisiin näkökulmiin ja lähestymistapoihin. Näiden kiinnostavuus onkin alkuperäistä ongelmaa tärkeämpi.

b) Ongelmien asettaminen. Uutta tietoa ei sulauteta suoraan aikaisempiin tietorakenteisiin, vaan rakennetaan omia teorioita ja selityksiä. Ongelman alkuperää tärkeämpää on niiden kiinnostavuus. Tärkeä merkitys on opiskelijoiden itsensä asettamien ongelmien ratkaisemisella. Tutkivalle oppimiselle ovat ominaisia aidot kysymykset, joihin ei tiedetä ja joihin ei yleensä ole etukäteen oikeaa vastausta.

c) Omien työskentelyteorioiden luominen kohteena olevasta ilmiöstä. Tavoitteena on, että opiskelija ulkoistaa omia tulkintojaan ja tuo ne yhteisöllisen pohdinnan kohteeksi.

d) Rakentava kriittinen arviointi. Oppimisyhteisö arvioi oman tutkimusprosessinsa edistymistä ja asettaa uusia tavoitteita. Vaihe edellyttää sitoutumista rakentavaan vuorovaikutukseen.

e) Uuden tiedon hankkiminen ja luominen. Opiskelijat testaavat alkuperäisiä työskentelyteorioita etsimällä uutta tietoa erilaisista tiedon lähteistä. Tutkivan oppimisen onnistumista voidaan arvioida sen perusteella, pystyvätkö opiskelijat luomaan asteittain monimutkaistuvia työskentelyteorioita, luopumaan tarvittaessa arkikäsityksistään ja löytämään tutkimuksen kohteena olevien ilmiöiden selittämisen ja ymmärtämisen kannalta merkityksellisiä käsitteitä, malleja ja viitekehyksiä. f) Tarkentuvan ongelman asettaminen. Tutkiva oppiminen on tarkentuva kysymys-vastaus -prosessi, jolloin ongelmaan löytyy ratkaisu yhden tai useamman tiedonhankintakierroksen jälkeen.

g) Jaettu asiantuntijuus. Kaikki oppimisen osaprosessit voidaan jakaa oppimisyhteisön jäsenten kesken. Tästä seuraa jaettu asiantuntijuus. Tiedon kehittyminen on koko oppimisyhteisön vastuulla.

h) Työskentelyteorian luominen. Edellä olevan prosessin perusteella voi parhaimmillaan syntyä uusi työskentelyteoria.

Hakkaraisen ym. (2004) mukaan tutkiva oppiminen voi tapahtua toteuttamalla kursseja tai oppimisprojekteja, joiden yleispuitteet ja aihepiiri voivat olla opettajan tai tutorin esittämiä. Opiskelijat vastaavat suunnittelusta ja toteutuksesta opettajan ohjauksessa.

Tiedon luomisen malleja on muitakin, kuin tässä käsitelty Hakkarainen \& Lonka \& Lipposen (2004) malli. Tässä esityksessä ei kuitenkaan ole tavoitteena suhteuttaa kyseistä mallia muihin vastaaviin (esim. Argyris, Dewey, Engeström, Kolb ja Schön). ${ }^{1}$

\section{KEHITTÄMISHANKKEEN KONTEKSTI}

Tarkastelemamme tutkivan oppimisen mallin konteksti rajoittuu Helsingin liiketalouden ammatti- 
korkeakouluun, liiketalouden koulutusohjelmaan, kansainväliseen yhteistyöympäristöön sekä yritysasiakkaalta tulleeseen toimeksiantoon. Kansainvälisyys tarkoittaa tässä monikulttuurista opiskelijaryhmää, yhteistyötä ulkomaisten yhteistyöoppilaitosten kanssa ja sitä, että kehittämishankkeen kohde on ulkomailla. Taustalla on kolmetoista vuosina 1996-2003 pääpiirteiltään samalla tavalla toteutettua kehittämishanketta. Niistä raportoidaan vuonna 2001 toteutettu, Espanjaan suuntautunut hanke, joka käsityksemme mukaan vastaa keskivertoprojektia. Raportoituun hankkeeseen osallistui Suomen ryhmässä 14 opiskelijaa, joista yhdeksän oli ulkomaalaisia vaihtoopiskelijoita. Espanjan ryhmä koostui 15 opiskelijasta. Oppimisprosessia ohjasi kummassakin maassa kaksi ohjaajaa.

Raportin taustalla olevissa kansainvälisissä kehittämishankkeissa kohdemaina olivat Espan- ja (2 hanketta), Iso-Britannia (2 hanketta), Latvia, Liettua, Ranska, Saksa (2 hanketta), Tanska, Turkki, Viro ja Yhdysvallat. Mukana olleet vaihto-opiskelijat edustivat seuraavia maita: Alankomaat, Bulgaria, Iso-Britannia, Italia, Itävalta, Kiina, Peru, Puola, Ranska, Saksa, Unkari, Venäjä ja Viro.

Kokeilu toteutettiin International Business Project Work -opintojaksona. Kehittämishankkeen tarkoituksena oli lisätä liiketalouden opiskelijoiden ongelmanratkaisu- ja päätöksentekotaitoja, kykyä luovaan ajatteluun, itseluottamusta sekä kykyä työskennellä paineen alaisena. Toimeksiantajat olivat suuria koti- tai ulkomaisia yrityksiä. Kukin toteutus oli asiakkaalle erikseen räätälöity. Opiskelijaryhmä muodostui kussakin tapauksessa suomalaisista ja ulkomaisista vaihtoopiskelijoista. Ryhmä oli kussakin maassa kooltaan useimmiten noin 10-20 henkeä, joista ydinryhmän koko oli 5-7 opiskelijaa².

\begin{tabular}{|c|c|}
\hline Osatekijä & Kansainvälinen kehittämishanke \\
\hline Konteksti & $\begin{array}{l}\text { Ammattikorkeakoulu, liiketalouden koulutusohjelma, kansainvälinen yhteis- } \\
\text { työympäristö, todellinen yritysasiakas, todellinen toimeksianto }\end{array}$ \\
\hline Opintoviikot & $\begin{array}{l}\text { 1-9, jokainen opiskelija pitää koko hankkeen ajan henkilökohtaista työ- } \\
\text { päiväkirjaa }\end{array}$ \\
\hline Ongelma & Monimuotoinen (kompleksinen, ei selviä ratkaisumalleja) \\
\hline Rahoitus & $\begin{array}{l}\text { Oppilaitos, asiakasyritys, ulkopuoliset rahoittajat, opiskelijat vastuussa } \\
\text { osasta hankekustannuksia }\end{array}$ \\
\hline Opiskelijan profiili & $\begin{array}{l}\text { Itseohjautuva, kyky työskennellä kansainvälisessä ympäristössä, } \\
\text { ongelmanratkaisutaito. Opiskelijat valitaan hakemuksen perusteella. }\end{array}$ \\
\hline Ryhmän profiili & Monitaitoinen, vahvasti sitoutunut, kyky hallita stressiä ja epävarmuutta \\
\hline Ohjaajan profiili & Fasilitaattori \\
\hline $\begin{array}{l}\text { Yhteistyöoppilai- } \\
\text { tosten profiili }\end{array}$ & $\begin{array}{l}\text { Kyky yhdistää eri oppilaitosten erilaiset oppimiskulttuurit, opetussuun- } \\
\text { nitelmien joustavuus ja soveltuvuus yritysyhteistyöhankkeisiin }\end{array}$ \\
\hline Oppimisympäristö & $\begin{array}{l}\text { Yhteiset opetussessiot, Blackboard (virtuaalinen), videokonferenssit } \\
\text { jne. yhteistyössä asiakasyrityksen kanssa }\end{array}$ \\
\hline $\begin{array}{l}\text { Hankkeen aikatau- } \\
\text { lu }\end{array}$ & $\begin{array}{l}\text { Määritellään yhteistyössä asiakasyrityksen kanssa. Edellyttää joustavaa } \\
\text { ajankäyttöä opiskelijaryhmältä. }\end{array}$ \\
\hline Raportointi & $\begin{array}{l}\text { Asiakasyritykselle, oppilaitokselle, noudattaen oppilaitoksen raportointi- } \\
\text { periaatteita }\end{array}$ \\
\hline Arviointi & $\begin{array}{l}\text { Nelikanta-arviointi: itsearviointi, vertaisarviointi, ohjaajien suorittama } \\
\text { arviointi sekä asiakasyrityksen suorittama arviointi. Työpäiväkirja }\end{array}$ \\
\hline $\begin{array}{l}\text { Tavoitteen asetta- } \\
\text { minen ja seuranta }\end{array}$ & Ohjaajat, opiskelijat, asiakasyritys \\
\hline
\end{tabular}


Yrityksille toteutettujen kansainvälisten kehittämishankkeiden osatekijöitä ovat muun muassa nelikanta-arviointi, yrityslähtöinen ongelma, hankeryhmän, ohjaajan ja yksittäisen opiskelijan roolien määräytyminen kulloisenkin toimeksiannon mukaan sekä erilaisten oppimiskäsitysten ja kulttuurien yhteensovittaminen. Hankkeiden osatekijöitä on kuvattu taulukossa 1.

Opiskelijoilla on ollut mahdollisuus käyttää ulkopuolista opiskelija-apua esimerkiksi kyselylomakkeen kääntämiseen harvinaiselle vieraalle kielelle tai aineiston tilastoajoon. Yhden yksilön ei tarvitse itse osata kaikkea, vaan hänen tulee kyetä hyödyntää muiden osaamista ja ajatuksia. Tämä edellyttää, että jäsenillä on hyvä käsitys toistensa osaamisesta (Lonka \& Hakkarainen 2000 Opiskelijat ovat alussa asettaneet henkilökohtaiset oppimis- ja opintoviikkotavoitteensa, jotka ovat vaihdelleet kunkin opiskelijan resurssien mukaan. Nämä ovat yhdessä mahdollistanee sitoutuneemman ja sitä kautta tehokkaamman työskentelyn. Opiskelijat ovat saaneet 1-9 opintoviikkoa työmääränsä mukaan, jonka he ovat dokumentoineet työpäiväkirjaansa.

\section{KOKEILUN TULOKSIA}

Kokeilun tuloksia käydään läpi kuvaamalla uuden mallin vaiheet (esitetään kokonaisuudessaan kuviossa 3) sekä niiden reunaehdot ja keskeiset osatekijät. Malli sisältää kaikki Hakkaraisen ym. (2004) tutkivan oppimisen mallin kahdeksan vaihetta, mutta olemme lisänneet siihen neljä uutta vaihetta. Lähtökohtaolettamuksia ja reunaehtoja käsitellään vaiheiden sisällä.

\section{TOIMEKSIANNON HANKKIMINEN JA ALUSTAVAN ONGELMAN MÄÄRITTELY}

Tämäntyyppisessä työskentelykulttuurissa fasilitaattorin rooli on varsin vaativa. Hanke alkaa paljon ennen opintojakson alkua ja se vaatii runsaasti etukäteisvalmistelua erityisesti toimeksiannon hankkimiseksi. Myös hankkeen räätälöinti kullekin asiakkaalle erikseen lisää työläyttä. Etukäteisneuvotteluissa mahdollisen asiakkaan kanssa on kummankin osapuolen voitava nähdä hankkeesta koituva hyöty. Yritysyhteistyö perustuu 'kaupankäynnin' win-to-win -periaatteeseen, jolloin asiakasyrityksen tulee saada jotain konkreettista vastiketta panokselleen. Tällainen vastike voi olla teoreettista tietämystä, kokemuksellista osaamista tai hankkeen tuottamaa empiiristä tie- toa. Erään asiakkaan kommentin mukaan: "I found out how little we know about partnership."(Kts. myös Härkäpää 2001 sekä Zaharia \& Uebersfeld \& Marina 2003).

Ongelman löytäminen edellyttää runsaasti etukäteistyötä. Tällöin ensin perehdytään potentiaalisiin asiakasyrityksiin, sen jälkeen analysoidaan niiden mahdollisia ulkomaille suuntautuvia selvitystarpeita ja sen jälkeen laaditaan muutama vaihtoehtoinen, konkreettinen tutkimusongelma, joista neuvotellaan asiakasyrityksen kanssa. Tämä vaihe voidaan toteuttaa yhteistyössä opiskelijoiden kanssa tai ilman heitä. Tässä kuvatussa hankkeessa tämä vaihe toteutettiin ilman opiskelijoita. Ongelmasta neuvoteltiin asiakasyrityksen kanssa ensimmäisen kerran maaliskuussa ja opiskelijat aloittivat hanketyöskentelyn vasta opintojakson alettua syyskuussa.

Hankkeissamme asiakasyritys on osallistunut alustavan ongelman määrittämiseen, tavoitteiden asettamiseen, arviointikohteiden ja kriteerien sekä tarkistuspisteiden määrittämiseen. Hankeryhmän täytyy seurata asiakkaan aikatauluja, mutta ne eivät välttämättä noudata oppilaitoksen muuta opiskelurytmiä.

Koska tutkivassa oppimisessa Ongelman asettaminen on olennaista, tässä voisi avata sitä, miten neuvotteluissa päädyttiin tiettyyn ongelma-asetteluun, ja kuinka esimerkiksi opiskelijat olivat sitä mahdollisesti mukana itse määrittelemässä?

\section{OPISKELIJARYHMÄN VALINTA}

Opiskelijaryhmä tulisi muodostaa siten, että se edustaisi erilaisia taitoja ja persoonallisuuksia. Skager (1984) on tunnistanut seitsemän itseohjautuvan oppijan persoonallisuuden piirrettä: itsensä hyväksyminen, suunnitelmallisuus, sisäinen motivaatio, omaehtoinen arviointi, avoimuus uusille kokemuksille, joustavuus ja itsenäisyys.

Kokemustemme mukaan Skagerin tunnistamat itseohjautuvan oppijan persoonallisuuden piirteet edesauttavat yrityksille toteutetun kansainvälisen hankkeen onnistunutta toteuttamista. Näistä keskeisimpiä ovat sisäinen motivaatio, joustavuus ja itsenäisyys. Ylitulkittaessa tutkivaan oppimiseen voi liittyä vaara, että kaikki opiskelu tapahtuu itseohjautuvasti ja ilman toimintaa jäsentäviä struktuureja (Hakkarainen ym. 2004). Tässä hankkeessa ohjaaminen kohdistuu paitsi oppimiseen, myös sosiaaliseen kontekstiin ja ryhmäprosessiin liittyviin ongelmiin. Tämä on luonnollista, koska yrityksille toteutettu kansainväli- 
nen kehittämishanke on intensiivinen ja nopeatempoinen prosessi. Kiireessä ja stressissä yksilöillä on taipumus käyttää vanhoja, aikaisemmin oppimiaan oppimisstrategioita. Uuden lähestymistavan omaksuminen edellyttää epävarmuuden sietoa.

Kokemustemme mukaan yksi kehittämisen kohde tämäntyyppisessä oppimistavassa voisi olla se, että 'paras käsitys' hankkeesta ja tutkivasta oppimisesta ei jäisi pelkästään ryhmän (opiskelija) vetäjille, vaan tieto ja kokemus jakautuisi tasaisemmin ryhmään. Ongelma johtunee opiskelijoiden erisuuruisista työmääristä, työn organisoinnista sekä vastuun jaosta. Ainoa (opiskelija) jäsen, jonka roolinsa puolesta on oltava selvillä hankkeen kaikista vaiheista, on opiskelijaryhmän vetäjä(t).

Opintojakson alussa opiskelijat keskustelivat siitä, kuinka tämä opintojakso mahdollisesti eroaisi muista opintojaksoista. Samalla he asettivat henkilökohtaiset oppimistavoitteensa. Seuraavassa on esitetty suoria lainauksia opiskelijoiden kommenteista. Opintojakson työskentelykielenä on englanti, joten täsmällisyyden varmistamiseksi vastaukset esitetään alkuperäiskielellä:

"To learn what's the difference between theoretical problem what we get from the teachers in class and a real problem for which nobody knows already the answer."

Henkilökohtaisten tavoitteiden asettamisen jälkeen hankeryhmä opiskelijavetoisesti määritteli yhdessä ryhmän yhteiset oppimistavoitteet. Ryhmän tavoitteet dokumentoitiin fläppitaululle ja niihin palattiin hankkeen myöhemmissä vaiheissa. Hankeryhmän oppimistavoitteissa korostuivat seuraavat asiat:

- aito kansainvälinen yritysyhteistyö
- hankejohtamisen taidot

- ongelmanratkaisutaidot

- monikulttuurinen tiimityö ja kokemusten saaminen erilaisista kulttuureista

- ymmärryksen lisääminen tutkivasta oppimisesta.

Opiskelijoita pyydettiin myös kuvaamaan itseään ryhmän jäsenenä, arvioimaan vahvuuksiaan ja kehittämiskohteitaan sekä asemoimaan itsensä oppijana:

"Yes, I find myself a top-down view person goal-orientated."

"I'm still trying to learn to let also others make decisions."

Tämän jälkeen keskusteltiin itsenäisestä ja itseohjautuvasta työskentelystä sekä yhdessä oppimisesta, jossa ryhmällä on kollektiivinen vastuu lopputuloksesta. Keskustelua herättivät myös opiskelijoiden ja ohjaajien roolit ja yhteistyö.

Opiskelijat ( $\mathrm{N}=14)$ asemoivat itsensä oppijoina kuvion 2 havainnollistamalla tavalla. ${ }^{3}$

Opiskelijat odottivat fasilitaattorilta herkkyyttä ja joustavuutta. Hankkeen alussa opiskelijat vaikuttivat sitoutuneilta/itsenäisiltä ja heidän odotuksensa ohjaajan roolista oli avustaja/motivoija. Kiireen ja stressin lisääntyessä (hankkeen loppupuolella) eräillä opiskelijoilla oli taipumus käyttäytyä vähemmän itsenäisesti ja he odottivat ohjaajan olevan enemmän autoritäärinen ja motivoiva.

Opiskelijat tunsivat olevansa sitoutuneita oppimiseen ja odottivat ohjaajalta oppimisen ohjaamista ja avustamista. Todennäköisesti erilaisissa kulttuureissa ohjaajan rooli on hyvin erilainen. Kuvatun hankkeen kaltaiset oppimistavat synnyttävät hämmennystä joissakin vaihto-opiske-

\section{OPISKELIJA}

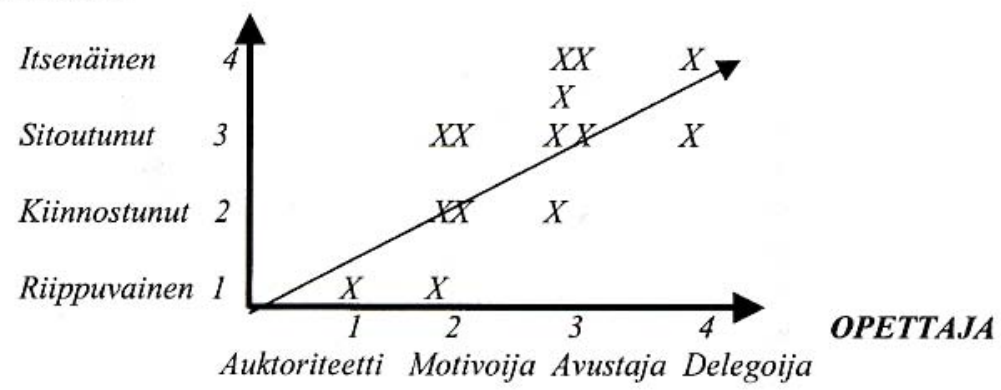


lijoissa, jotka tulevat toisenlaisista oppimiskulttuureista. Hankkeen kesto (6 kk) ei ole riittävän pitkä aika aiempien oppimistyylien ja -strategioiden poisoppimiseksi.

\section{HANKERYHMÄN ORGANISOITUMINEN}

Hankeryhmän organisoitumisella tarkoitetaan tässä tapauksessa työn ja vastuun jakamista, työskentelyaikataulun määrittämistä, neuvotteluja yhteistyöoppilaitoksen ja oman organisaation eri osien kanssa, budjetin rakentamista, matkasuunnitelman laatimista ja muita valmistelevia osin hallinnollisia tehtäviä, jotka eivät kuulu normaaliin opintojaksoon. Kaikkia näitä ei tässä yhteydessä ole erikseen selvitetty. Yrityksen rooli organisoitumisvaiheessa oli esimerkiksi sitoutua rahoittamaan osa hankkeen kustannuksista. (vrt. Miettinen \& Peisa 2002). Hankeryhmä organisoituu osaamisalueiden perusteella, jolloin opiskelijoille tulee omaan osaamiseen perustuvat vastuualueet. Tätä voidaan pitää myös motivoivana tekijänä.

Hankeryhmän organisoitumisen ajatuksena on ’jäljitellä’ tyypillisiä professionaalisia tiedonrakentamiskäytänteitä erotuksena yrittää organisoida oppimisyhteisö toimimaan tiedeyhteisön tapaan. (vrt. Hakkarainen ym. 2004). Tällöin nostetaan esille työelämän toimintamallien elementtejä, joihin kuuluvat muun muuassa ryhmän sosiaalistumisen korostaminen ryhmää valittaessa tai joustava ajankäyttö hanketta toteutettaessa.

Kysyttäessä opiskelijoilta työn delegoinnista ja vastuun ottamisesta omasta työstään he vastasivat:

"Each person is responsible for his/her own part but anyway if she/he has a problem, the team can help him/her."

Työskentelyaikataulut sekä yhteisiin tapaamisiin osallistuminen nousivat myös esille aineistossa. Kansainvälinen kehittämishanke edellyttää hyvin joustavaa työskentelytapaa nimenomaan ajankäytön suhteen. ${ }^{4}$ Opiskelijoiden vastausten perusteella näyttäisi siltä, että he uskovat hallitsevansa ajankäytön.

"I have not many courses, I can be present for each meetings. About the timetable we have to discuss."

Kokonaisuutena näyttäisi siltä, että opiskelijat suhtautuvat vakavasti ja luottavaisesti hankkeen organisoitumiseen. Toisaalta yritykselle toteutet- tu kansainvälinen kehittämishanke on heille usein kuitenkin ensimmäinen tämänkaltainen oppimiskokemus, jolloin ei voitane olettaakaan, että opiskelija pystyy tässä vaiheessa oppimisprosessia hahmottamaan ja omakohtaistamaan työskentelyprosessia. Tämä vaihe on hankkeen onnistumisen kannalta varsin työläs ja toisaalta kriittinen tekijä. Hakkarainen ym. (2004) eivät mallissaan ota huomioon lainkaan tätä vaihetta, ehkä siksi, että heidän tarkastelussaan tutkiva oppiminen asettuu enemmän oppilaitosympäristöön.

\section{OPETUKSEN ANKKUROINTI KONTEKSTIIN}

Opiskelijoiden tulisi luoda kehittämishankkeen konteksti aikaisempiin kokemuksiin ja tietoihin pohjautuen. Tässä vaiheessa mahdolliset puutteet oppimistaidoissa havaitaan konkreettisesti. Tähän asti oppimisprosessi on voinut sujua joustavasti, mutta tästä eteenpäin opiskelijalta odotetaan itsenäistä panosta.

Oppimistilanteissa opettajan on hallittava oma substanssiosaamisensa ja oltava siinä asiantuntija. Tutkimuskysymykset tulevat aidoista ja monimuotoisista yrityselämän ongelmatilanteista. Kysymys voi tällöin olla hyvin spesifinen ja tarkasti rajattu. Kaikki kysymykset eivät välttämättä kuulu kaikilta osin ohjaajan normaaliin osaamisalueeseen. Tämä edellyttääkin ohjaajalta joustavuutta: ohjausta tulee voida antaa omaan asiantuntemukseen liittyvien teemojen ulkopuolelta. Aihealueen kuuluessa ohjaajan substanssialueen ulkopuolelle joudutaan hankkimaan ainakin jossain määrin ulkopuolista substanssiosaamista. Tällöin ohjaajat eivät ole pelkästään fasilitaattorin vaan myös oppijan roolissa.

Kontekstin luomisvaiheessa motivointikeinoina on käytetty esimerkiksi vierailijoita, vierailuita, videoita ja artikkeleita.

\section{TUTKIMUSKYSYMYKSEN TÄSMENTÄMINEN}

Hankkeen aikana toimeksiantajayritykselle saattaa tulla uusia ajatuksia, jotka johtavat tutkimuskysymyksen täsmentämiseen. Tämä tapahtuu kuitenkin aina yhteistyössä oppilaitosten ja toimeksiantajayrityksen kanssa. Mikäli kysymys täsmennetään, muutos dokumentoidaan myös hankesuunnitelmaan. Esimerkkinä täsmentymisestä on maantieteellisen kohdealueen täsmentyminen (ei koko Espanja, vaan kolme nimettyä maakuntaa). 
Käytettäessä aitoja ongelmia tutkivan oppimisen lähtökohtana on tärkeää luoda yhteyksiä alkuperäisiin tietolähteisiin ja asiantuntijakulttuureihin (Hakkarainen ym. 2004). Toteutuksessa on käytetty tietolähteinä ulkopuolisia asiantuntijoita (esimerkiksi astmalääkäri, Suomen osteoporoosiyhdistys, Designmuseo) tai oman organisaation asiantuntijoita.

\section{TYÖSKENTELYTEORIAN LUOMINEN}

Hakkaraisen ym. (2004) mukaan ”jokainen ajatus on kehittelyn arvoinen”, kuitenkin kriittisessä mielessä. Työskentelylle pyrittiin luomaan ilmapiiri, joka kannusti opiskelijoita esittämään ajatuksiaan. Asiakkaalta tullut toimeksianto asettaa toiminnalle kuitenkin tietyt, tiukat reunaehdot, joiden puitteissa työskentelyteoriaa kehitetään. Yritys mahdollisti hankeryhmälle pääsyn yrityksen tiedon lähteille (vrt. Miettinen \& Peisa 2002).

Virtuaalinen oppimisympäristö (Blackboard) helpottaa yhteistyötä sekä asiakasyrityksen että yhteistyöoppilaitoksen kanssa ja erityisesti silloin, kun tuotetaan paljon uutta materiaalia ja luodaan työskentelyteoriaa, jonka tulee olla kaikkien osapuolten saatavilla samaan aikaan. Virtuaalinen oppimisympäristö tarjoaa asiakasyritykselle mahdollisuuden seurata työskentelyn etenemistä reaaliaikaisesti.

Yritysten resurssit tutkimus- ja kehitystoimintaan sekä uuden tiedon hankkimiseen ovat rajalliset (vrt. Zaharia \& Uebersfeld \& Marinas 2003). Verkostomuotoinen työskentely tarjoaa mahdollisuuden yhdessä oppimiseen.

\section{RAKENTAVAA KRIITTISTÄ ARVIOINTIA NELIKANTA- PERIAATTEELLA}

Arviointi suoritettiin nelikanta=periaatteella, jolloin siihen osallistuivat opiskelijat, vertaisopiskelijat, ohjaajat ja asiakasyrityksen edustajat.

Yrityksen edustajat arvioivat opiskelijoiden työskentelyprosessia sekä heidän esittämiensä ratkaisumallien ja kehitysehdotusten laatua ja käyttökelpoisuutta (vrt. Miettinen \& Peisa 2002). Yrityksen asettamat arvioinnin kohteet ja kriteerit eivät välttämättä ole yhtenevät oppilaitoksen asettamien arvioinnin kohteiden ja kriteerien kanssa. Tällöin on löydettävä yhtenäinen näkemys käytettävistä arvioinnin kohteista ja kriteereistä kehittämishankkeen alussa. Nämä on käytävä läpi myös opiskelijoiden kanssa ja heidän on hyväk- syttävä ne. Toteutetussa hankkeessa luvattu väliraportti lähetettiin yritykselle päivän myöhässä, mikä aiheutti asiakkaan edustajan puolelta kriittisen kommentin "epäammattimaisesta työskentelystä”.

Työskentelyn laatua arvioidaan mm. kustannusten perusteella. Kustannuksia ei saa ylittää. Hankkeen laatu kuvastaa oppilaitoksen laatua ja toimii referenssinä. Kansainvälisessä hanketyöskentelyssä kotimaisen oppilaitoksen on mentävä takuuseen myös ulkomaisen yhteistyöoppilaitoksen työn laadusta.

$\mathrm{H}$ ankkeen päättyessä opiskelijoita pyydettiin kirjoittamaan lyhyt essee koko tutkivan oppimisen prosessista. Heille annettiin teema-aiheet, joita piti käsitellä esseessä: odotukset koko prosessista ja niiden täyttyminen, kriittiset vaiheet hanketyöskentelyssä, yhteistyön toimivuus, oma oppiminen ja hanketyöskentelyn kehittämiskohteet. Asiaa havainnollistavat seuraavat opiskelijasitaatit:

\section{Opiskelijoiden henkilökohtaisia oppimistavoit- teita}

। opiskelijat kokivat saavuttaneensa henkilökohtaiset oppimistavoitteensa

"It encouraged me to work others as I am more comfortable with independent work. It also helped me to learn about a project progresses as well as more knowledge about the analyses and interpretation of research data."

\section{Onnistumisen paikkoja}

। työskentely monikulttuurisessa ryhmässä

"During this project the combination of different cultural background was more productive rather than working with people from the same cultural background."

I työskentely todelliselle asiakkaalle

"Work with the client (meetings, feedback)"

"Professional perspectives: To work on something so concrete with an economical reason behind."

I itseluottamuksen kasvaminen

"I felt pressure sometimes but I believe it is good as that is what the business life is about."

\section{Hanketyöskentelyn kehittämiskohteita (eniten mainintoja saivat)}

kommunikaatio 
"To express yourself in another language is sometimes harder than you think!!"

I työnjako

"Work division"

I hankepäällikkö (opiskelija)

"A (student)project manager could have taken more responsibility and carried out leadership"

Yhteenvetona näyttäisi siltä, että monikulttuurisessa työskentely-ympäristössä toimiminen tarjoaa suuren mahdollisuuden ja haasteen. Opiskelijoiden omien arvioiden mukaan heidän itseluottamuksensa ja suvaitsevaisuutensa kasvoivat. "I have learned how to be more understanding and tolerant towards people who do not have exactly the same set of values than mine".

Työskentely todelliselle asiakasyritykselle lisäsi opiskelijoiden opiskelumotivaatiota ja sitoutti heidät hankkeeseen. Samaan tulokseen päätyivät myös Miettinen \& Peisa (2002) tutkiessaan vaihtoehtoyrityskehittämishanketta. Yhdeksi viestinnän häiriötekijäksi nousi esille kurssikielenä käytetty englanti. Vain muutamalla harvalle opiskelijalle englanti oli äidinkieli, jolloin useimmat toimivat viestinnällisesti haastavassa tilanteessa.

Yhtenä kehittämiskohteena nousivat esille sisäiseen työnjakoon liittyvät kysymykset. Kokonaistavoitteen saavuttamiseksi joissakin tilanteissa ohjaajien on täytynyt puuttua ryhmän sisäiseen työnjakoon. Tämä ilmiö korostunee erityisesti monikansallisessa opiskelijaryhmässä, jossa lähtökohtaolettamukset ja odotukset työnjaosta ja rooleista ryhmässä ovat erilaisia. Koko hankkeen onnistumisen kannalta ohjaajien kannattaa nähdä erityistä vaivaa etsittäessä opiskelijoiden joukosta hankeryhmälle vetäjiä. Vetäjän oma esimerkki, sitoutuminen ja yhteistyötaidot edesauttavat olennaisesti opiskelijaryhmän työskentelyä ja sitä kautta hankkeen onnistumista.

Voidaan ajatella, että tämän tyyppistä työskentelyä edesauttaisi, mikäli opintojen aikaisemmissa vaiheissa opiskelijoita olisi harjaannutettu lukemansa materiaalin kriittiseen arviointiin ja kykyyn analysoida laadittujen selvitysten vahvuuksia ja heikkouksia.

\section{SYVENTÄVÄN TIEDON HANKKIMINEN}

Tutkivan oppimisen tarkoituksena on uuden tiedon synnyttäminen, johon kiinteästi liittyy opis- kelijoiden kehittämien työskentelyteorioiden testaaminen (Hakkarainen ym. 2004). Yrityksen tarpeista lähtevän hankkeen lähtökohtana on tutkimusongelman ratkaiseminen uuden syventävän tiedon avulla. Tutkivaan oppimiseen teoreettisessa mallissa aikaa on käytettävissä periaatteessa rajattomasti. Käytännössä tässä hankkeessa ei aikataulullisista syistä ollut mahdollista käyttää samassa määrin resursseja opiskelijoiden kehittämien työskentelyteorioiden testaamiseen. Näyttäisi siltä, että opiskelijoiden valmiudet annetuissa rajoissa löytää kohteena olevan ilmiön selittämisen ja ymmärtämisen kannalta merkityksellisiä malleja ja viitekehyksiä ovat jonkin verran riittämättömät. Tämä vaihe onkin usein vaatinut fasilitaattorin apua. Fasilitaattorin rooliksi ei riitä pelkästään se, että on kiinnostunut opiskelijoiden oppimisesta ja heidän ajatuksistaan (vrt. Tordtenddon \& Menani 2003). Opiskelijoiden itseohjautuvaa oppimista on täydennettävä erityyppisillä strukturoiduilla oppimistilanteilla, kuten harjoituksilla ja asiantuntijatapaamisilla. Prosessin tässä vaiheessa opiskelijat ovat aktiivisia oppimistilanteissa, koska niistä voidaan saada vastauksia tutkimusongelmaan liittyviin kysymyksiin. Uuden tiedon kehittämisen prosessissa olennaista on se, ettei opiskelijoiden tiedollinen ponnistelu jää vain omien työskentelyteorioiden esittämiseen, vaan siihen yhdistyy ulkopuolisten lähteiden käyttöä.

\section{TARKENTUVAN ONGELMAN ASETTAMINEN}

Toimeksiantajayritys haluaa usein ennen varsinaista raportointia etukäteen tutustua saatuihin tuloksiin ja niiden argumentteihin. Nämä tulokset voivat johtaa vielä tarkennettuihin ohjeisiin viimeisiä analyyseja varten ja samalla ne antavat toimeksiantajayritykselle mahdollisuuden valmistua raportointitilaisuuteen. Varsin usein saadut tulokset herättävät uusia tutkimusongelmia, joita ei saman hankkeen puitteissa pystytä ratkomaan, vaan ne siirtyvät jatkohankkeiksi tai opinnäytetöiksi. Tässä kuvattu hanke jatkui kahdella opinnäytetyötoimeksiannolla. Hakkarainen ym. (1999) toteavat, että tutkiva oppiminen on parhaimmillaan spiraalinomaisesti syvenevä prosessi, jossa alun epämääräiset kysymykset ja teoriat muuttuvat täsmällisemmiksi ja paremmin perustelluiksi. Mallissa tämä voi tarkoittaa palaamista aikaisempiin tutkivan oppimisen vaiheisiin. 


\section{JAETTU ASIANTUNTIJUUS}

Jaetulla asiantuntijuudella tarkoitetaan "pedagogista käytäntöä, jossa vastuuta oppimisprosessista jaetaan opettajan ja oppilaan välillä sekä oppilaiden välillä siten, että oppimisyhteisön jäsenet perehtyvät syvällisemmin heitä itseään kiinnostaviin asioihin ja opettavat niitä toinen toisilleen” (Hakkarainen \& Lipponen \& Ilomäki \& Järvelä \& Lakkala \& Muukkonen \& Rahikainen \& Lehtinen 1999). Jaettu asiantuntijuus toimii opiskelijoille myös motivoivana tekijänä.

Asiakasyrityksen yhteyshenkilön rooli (IBPW:ssä yrityksen johtoon kuuluva henkilö) on maksava asiakas eikä ohjaaja tai fasilitaattori.

\section{KEHITYSEHDOTUSTEN LUOMINEN}

Asiakasyritys tavoittelee konkreettista hyötyä toimeksiannosta. Hyötynä voi olla esimerkiksi selvittää tuotteelle Saksan markkinoilla asetettava hinta, löytää uusia tavarantoimittajia Espanjan markkinoilla tai kartoittaa skandinaavisten hotelliasiakkaiden odotuksia Turkin markkinoilla. Tulokset toimivat yrityksissä usein investointipäätösten perustana. Kun aitoa, maksavalle asiakasyritykselle tehtävää kehittämishanketta verrataan caseen, niin ratkaisuvaihtoehtojen ja johtopäätösten on oltava realistisia ja perustuttava saatuihin tuloksiin. Casea ratkaistaessa on paljon enemmän joustavuutta ja ratkaisuvaihtoehtoja. Käytännön asettamat rajoitukset ovat tiukempia ja monimutkaisempia kuin pelkistetyissä case -harjoituksissa. Johtopäätöksiä pitää voida käyttää aidossa liiketoimintaympäristössä. Kehitysehdotusta arvioivat liike-elämän asiantuntijat omista lähtökohdistaan.

\section{JAETTU ASIANTUNTIJUUS MOTIVOI}

Jaetulla asiantuntijuudella tarkoitetaan "pedagogista käytäntöä, jossa vastuuta oppimisprosessista jaetaan opettajan ja oppilaan välillä sekä oppilaiden välillä siten, että oppimisyhteisön jäsenet perehtyvät syvällisemmin heitä itseään kiinnostaviin asioihin ja opettavat niitä toinen toisilleen” (Hakkarainen \& Lipponen \& Ilomäki \& Järvelä \& Lakkala \& Muukkonen \& Rahikainen \& Lehtinen 1999). Jaettu asiantuntijuus toimii opiskelijoille motivoivana tekijänä.

Kuvatussa hankkeessa asiakasyrityksen yhteyshenkilön rooli on maksava asiakas eikä ohjaaja tai fasilitaattori. Asiakasyritys haluaa tutkimusongelman ratkaisemista prosessin mahdollis- taessa myös yhdessä oppimisen. Useimmiten asiakasyritykset painottavat opiskelijoille, että yrityksessä työskennellään kovassa paineessa. Yritykset ovat kuitenkin halukkaita tarjoamaan opiskelijoille mahdollisuuden työskennellä yhteistyössä heidän kanssaan ja oppia heidän hiljaisesta tiedostaan. Käytännössä opiskelijat ovat opiskellessaan omaksuneet tietynlaisen oppimiskulttuurin, jossa ohjaaja on aina käytettävissä ja he helposti rinnastavat yrityksen edustajat ohjaajaan. Todellisuudessa yrityksen edustajat toimivat kuitenkin asiakassuhteisiin sopivalla tavalla, jolloin yritys antaa toiselle osapuolelle aikaansa vain rajallisen määrän. Tämän tyyppisessä hankkeessa oppiminen tapahtuu ikään kuin sivutuotteena ratkottaessa todellisia työhön liittyviä ongelmia.

\section{ASIAKAS- JA OPPILAITOSYHTEIS- TYÖN YLLÄPITO JA JATKOHANKKEET}

Tämän kokeilun kohteena olleet tutkivan oppimisen hankkeet eivät pääty raportointiin. Hyvin toteutettu kehittämishanke voi tarjota mahdollisuuden erilaiseen jatkoyhteistyöhön. Koeteltu ja toimivaksi havaittu yhteistyö tarjoaa "kaupankäyntimahdollisuuksia” (Härkäpää 2001).

Oppilaitoksen täytyy kuitenkin pitkällä tähtäimellä sitoutua tämänkaltaiseen opetusmenetelmään. Ammattikorkeakoululla tulisi olla sekä kansainvälistymis- että partneristrategia. Tällainen hanke vaatii enemmän resursseja kuin perinteinen opintojakso. Yrityslähtöiset hankkeet ovat enemmänkin osa ammattikorkeakoulun strategiaa ja imagoa. Tämä opetusmenetelmä tarjoaa aidon kansainvälisen työskentely-ympäristön.

Toisaalta tällainen intensiivinen tutkimushanke vaatii työskentelytiloikseen enemmän kuin pelkästään oppilaitoksen lukujärjestykseen varatun luokkatilan; esimerkiksi tilan, missä voi säilyttää luottamuksellista tutkimusmateriaalia ja missä ovat muut tarvittavat työskentelyvälineet. Ongelmaperusteisen oppimisen tavoin työelämälle toteutettu kansainvälinen tutkimushanke vaikuttaa opetussuunnitelmaan, opetuksen organisointiin ja oppimisen ohjaamiseen (Poikela 2003).

Edellä on kuvattu yrityksille toteutettuja kansainvälisiä kehittämishankkeita ja niiden eri elementtejä. Tavoitteena on ollut lähentää oppimista kohti aitoja yrityselämän ammattikäytäntöjä. Työskentely rakentuu yhden ison kehittämistehtävän ympärille, joka koostuu pienemmistä toisiaan tukevista ongelmista. 


\section{JOHTOPÄÄTÖKSET}

Yrityksille toteutetut kansainväliset tutkimushankkeet sovellettuna tutkivan oppimisen malliin (Hakkarainen ym. 2004) ovat tavallisesti suuri haaste opiskelijoille, opettajille ja opetusta järjestävälle instituutiolle. Opiskelijat saattavat tuntea olonsa epävarmaksi joutuessaan ottamaan vastuuta sekä koko prosessista että lopputuloksesta. Johnson \& Snaithin (1998) mukaan yksinkertaisimmat omaksumismallit tällaisessa tilanteessa ovat: opiskelijat yrittävät selviytyä haasteesta, opiskelijat yrittävät välttää haasteita tai opiskelijat yrittävät selviytyä yrityksen ja erehdyksen kautta. Tällaisessa hankkeessa opiskelijat ovat toisistaan riippuvaisia, kommunikoivat keskenään, ovat aikatauluihin sidoksissa ja heillä on keskinäinen työnjako tutkimusongelman ratkaisemiseksi. Kokonaisuutena arvioiden he kuitenkin yrittävät selviytyä haasteesta.

Kun tutkivaa oppimista toteutetaan perinteisessä oppilaitosympäristössä, ongelmiksi saattavat nousta työjärjestyksiin liittyvät kysymykset sekä usein rajalliset resurssit. Käytännössä työskentelyä ei voi rajoittaa pelkästään työjärjestyksessä etukäteen määriteltyihin tunteihin, vaan hanketta on työstettävä myös iltaisin tai viikonloppuisin. Eräänä keskeisenä ongelmana on myös sopivien arviointikriteerien löytäminen (vertaa Eteläpelto \& Rasku-Puttonen 1999).

Yrityksille toteutettujen kansainvälisten tutkimushankkeiden etuja ovat yhdessä oppiminen, opiskelijoiden mahdollisuus työskennellä itsenäisesti sekä se, että oppimisessa voi päästä syvemmälle. Työskentely pidemmän aikaa saman ongelman ympärillä tarjoaa opiskelijoille mahdollisuuden henkilökohtaiseen kasvuun sekä perinteiseen oppimistehtävään verrattuna todellisen onnistumisen tunteen.

Kokemustemme mukaan yksi kehittämisen kohde tämän tyyppisessä oppimistavassa voisi olla se, että 'paras käsitys' hankkeesta ja tutkivasta oppimisesta ei jäisi pelkästään ryhmän (opiskelija) vetäjille, vaan tieto ja kokemus jakautuisi tasaisemmin hankeryhmään.

Ongelma johtunee opiskelijoiden erisuuruisista työmääristä, työn organisoinnista sekä vastuun jaosta. Ainoa (opiskelija)jäsen, jonka roolinsa puolesta on oltava selvillä hankkeen kaikista vaiheista, on opiskelijaryhmän vetäjä(t).

Kuviossa 1 esiteltiin tutkivan oppimisen osatekijät Hakkaraisen ym. (2004) mukaan. Teoreet- tista mallia on arvioitu soveltamalla sitä kansainvälisissä, todelliselle asiakkaalle toteutetuissa hankkeissa. Merkittävimmät erot teoreettisen mallin ja käytännön välillä ovat (suluissa olevat kohdat viittaavat kuvioon 3):

- Yritysperustaisella hankkeella on oltava todellinen toimeksianto (kohta 1).

- Opiskelijaryhmän valinta vaikuttaa ratkaisevasti lopputulokseen (kohta 2).

- Opiskelijoiden pitää olla normaalia enemmän itseohjautuvia (kohta 2).

- Hankeryhmä organisoituu (kohta 3).

- Hankeryhmää motivoidaan ja sosiaalistetaan (kohdat 2-11).

- Käytännön tasolla joudutaan tekemään huomattava määrä valmistelevia ja hallinnollisia toimenpiteitä (kohdat 1, 3 ja 12).

- Ryhmän täytyy huomioida myös asiakkaan aikataulu (kohdat 3, 5, 7 ja 10).

- Yrityselämään liittyvän hankkeen tuotoksena on todellinen kehitysehdotus toimeksiantajalle (kohta 10).

- Laatuvaatimukset ovat korkeammat todellisesta, maksavasta asiakkaasta johtuen (kohta 10).

- Yrityselämään perustuva hanke mahdollistaa ja edellyttää asiakas- ja oppilaitossuhteiden ylläpitämistä (kohta 12).

- Virtuaalinen oppimisympäristö (Blackboard) mahdollistaa reaaliaikaisen yhteydenpidon toimeksiantajaan ja yhteistyöoppilaitokseen. Asiakasyritys voi, niin halutessaan, seurata hanketyöskentelyn etenemistä (kohta 13).

- Ohjaajan rooli on enemmän fasilitaattori kuin opettaja/tutor (kohdat 1-13).

Kuviossa 3 on täydennetty Hakkarainen ym. (2004) tutkivan oppimisen teoreettista mallia tutkimustulostemme perusteella lisäämällä kuvioon kohdat 1, 2, 3, 12 ja 13.

Yrityselämälle toteutettava hanke edellyttää toimeksiannon hankkimista useita kuukausia ennen varsinaisen oppimisprosessin alkamista (vaihe 1). Toimeksiannot ovat sen verran vaativia, että ne edellyttävät monialaista ja poikkitieteellistä osaamista. Onnistumisen varmistamiseksi opiskelijat valitaan hankeryhmään hakemusten perusteella (vaihe 2). Koko prosessi on niin monitahoinen, että onnistuminen edellyttää huolellista organisointia (kohta 3). Vasta näiden vaiheiden jälkeen päästään Hakkaraisen ym. (2004) kuvaamaan oppimisprosessiin. Prosessi ei pääty opintojakson loppumiseen, vaan hankkeen jäl- 


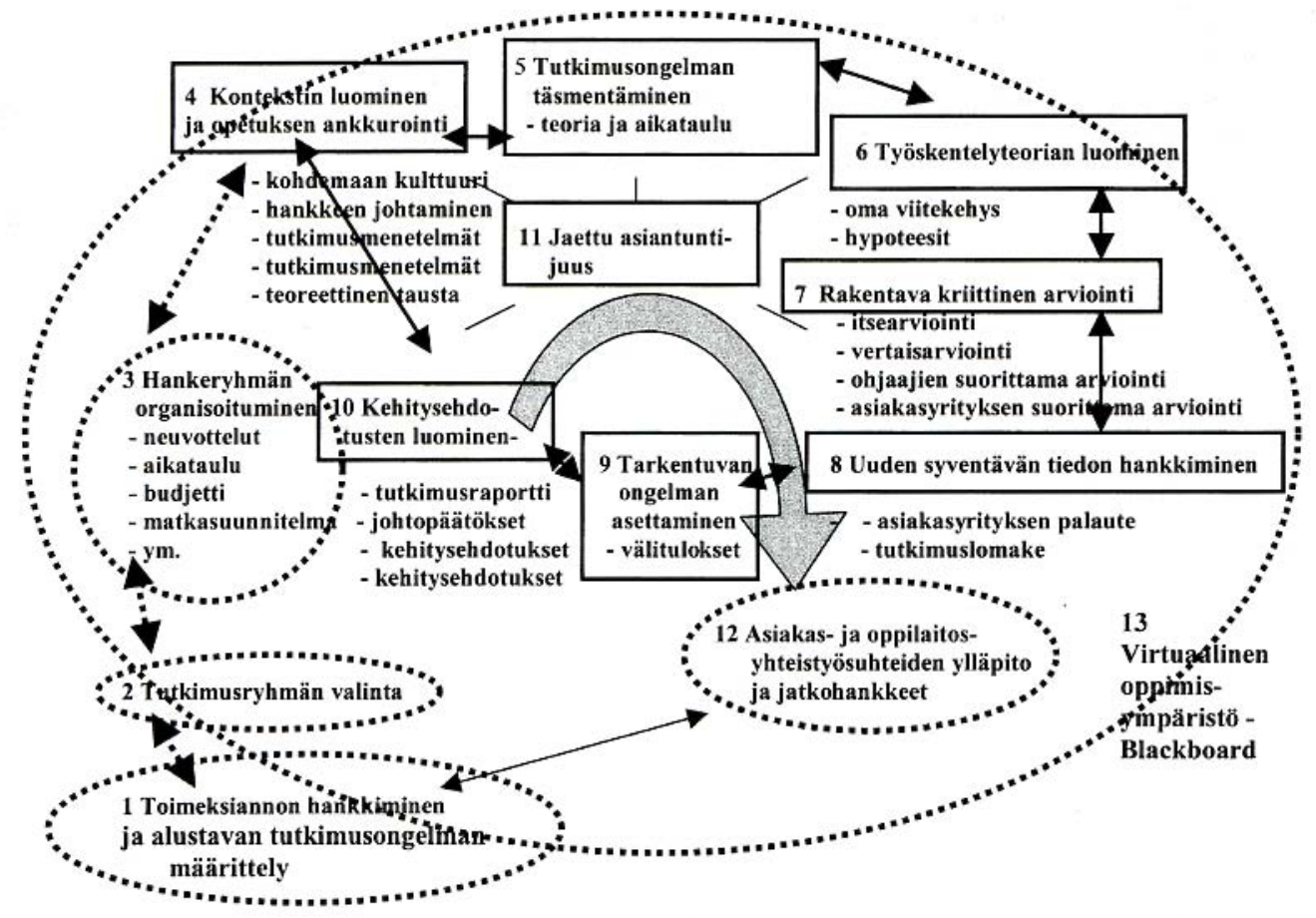

\section{KUVIO 3: HAKKARAINEN YM. (2004) TUTKIVAN OPPIMISEN MALLI SOVELLETTUNA TYÖELÄMÄLLE TOTEUTETUN KANSAINVÄLISEN TUTKIMUSHANKKEEN KONTEKSTIIN.}

keen on ohjaajien ylläpidettävä suhteita toimeksiantajaan, yhteistyöoppilaitoksiin ja muihin sidosryhmiin (vaihe 12). Virtuaalinen oppimisympäristö mahdollistaa kaikille asianosaisille pääsyn hankemateriaaliin reaaliaikaisesti edesauttaen joustavaa työskentelyä (vaihe 13). Tämä edellyttää teknisiä resursseja ja valmiutta hallita virtuaalista oppimisympäristöä. Toisaalta myös tieto siitä, että materiaali on asianosaisten käytettävissä luo laatupaineita.

Hankkeessa teoria ja käytäntö linkittyvät yhteen, jolloin oppimisen ja käytännön tekemisen välillä on joiltakin osin mahdotonta tehdä selvää eroa. Myös vaiheiden tiukka jäsentäminen on hankalaa, osa vaiheista (esimerkiksi budjetti, matkasuunnitelma) täsmentyy vasta prosessin kuluessa. Prosessin edetessä on myös mahdollista palata takaisin aikaisempiin vaiheisiin. Tutkivan oppimisen malli on enemmänkin työkalu, jolla jäsennetään käytännön toimintaa.

Kansainväliset kehittämishankkeet ovat vaativia ja onnistuminen edellyttää monenlaista osaamista, mutta tarjoaa myös mahdollisuuden ammatilliseen kehittymiseen. Onnistumisen varmis- tamiseksi ohjaajia on kaksi, jotka pääsääntöisesti ohjaavat ryhmää samanaikaisesti. Tällöin myös ohjaajat oppivat eri tavalla verrattuna perinteiseen yksintyöskentelyn traditioon. Kokonaisuutena kahden ohjaajan järjestelmä on osoittautunut toimivaksi.

Tutkivan oppimisen mallin (Hakkarainen ym. 2004) ja yrityselämälähtöisen kansainvälisen kehittämishankkeen prosessien vaiheiden ja keskeisten osatekijöiden välillä on eroavaisuuksia. Malli antaa kuitenkin hyvän perustan tämän tyyppiselle työskentelylle. Saamiemme tulosten perusteella olemme kehittäneet em. mallia enemmän yritysperusteiseen kontekstiin sopivaksi. Todellinen asiakas ja yhteistyöoppilaitos tekevät prosessin paljon monimutkaisemmaksi ja vaativammaksi kuin pelkän teoreettisen mallin perusteella voisi päätellä. Käytännössä yrityselämän ammattikäytänteitä ei voida yksi yhteen siirtää oppilaitosympäristöön vaan ainoastaan tuoda ehkä lisääntyvässä määrin yrityselämän elementtejä oppilaitosympäristöön. Tämän tyyppisen opetusmenetelmän mukanaan tuomia valmiuksia opiskelijat tarvitsevat yrityselämässä yhä enemmän. 
Edellä mainitut erot johtuvat erilaisista lähtökohtaolettamuksista ja reunaehdoista. Kun tutkivaa oppimista toteutetaan perinteisessä oppilaitosympäristössä, ongelmiksi saattavat nousta työjärjestyksiin liittyvät kysymykset sekä usein rajalliset resurssit. Käytännössä työskentelyä ei voi rajoittaa pelkästään työjärjestyksessä etukäteen määriteltyihin aikoihin, vaan hanketta on työstettävä tarpeen vaatiessa myös iltaisin tai viikonloppuisin. Eräänä keskeisenä ongelmana on myös sopivien arviointikriteerien löytäminen (vrt. Eteläpelto \& Rasku-Puttonen 1999). Tämän tyyppiseen hankkeeseen liittyy olennaisina osina toimeksiantosopimuksen tekeminen, budjetointi, rahoituksen hankkiminen ja rahaliikenteen hoitaminen, joita ei voida pitää normaaliin opintojaksoon kuuluvina toimintoina.

Tulevaisuudessa yrityselämälle toteutettu kansainvälinen hanke voisi vielä enemmän ylittää rajapintoja. Tällöin yrityksen rooli muuttuisi aktiivisemmaksi toimijaksi. Tämä antaisi opiskelijoille ja opettajille mahdollisuuden päästä vieläkin lähemmäksi yrityselämän ammattikäytäntöjä sekä antaisi edellytyksiä entistä paremmin yhdessä oppimiseen.

\section{LÄHTEET}

Ammattikorkeakoululaki, 9.5.2003/351.

Castells, M. (1996). The rise of the new network society. The information age: economy, society and culture volume I. Blackwell Publishers.

Eteläpelto, A. \& Rasku-Puttonen, H. (1999). Hankeoppimisen haasteet ja mahdollisuudet. Teoksessa Eteläpelto, A. \& Tynjälä, P.(toim.) Asiantuntijuus ja oppiminen. Työelämän ja koulutuksen näkökulmia. WSOY.

Hakkarainen, K. \& Lipponen, L.e \& Ilomäki, L. \& Järvelä, S. \& Lakkala, M. \& Muukkonen, H. \& Rahikainen, M. \& Lehtinen, E. Tieto-ja viestintätekniikka tutkivan oppimisen välineenä. Helsingin kaupungin opetusvirasto. Tietotekniikkaprojektin tutkimusryhmä. http.//www.hyvan.helsinki.fi/tutkiva/, 02.02.2004

Hakkarainen, K., Lonka, K. \& Lipponen, L. (1999).Tutkiva oppiminen - älykkään toiminnan rajat ja niiden ylittäminen. WSOY.

Hakkarainen, K., Lonka, K. \& Lipponen, L. (2004). Tutkiva oppiminen - järki, tunteet ja kulttuuri oppimisen sytyttäjänä. WSOY.

Hannon, Stephen \& McBride, Hugh \& Burns, Barbara (2003). Using Experimental learning Techniques to Develop Creative and Critical Thinking Abilities in Business Graduates, teoksessa New Horizons in Industry and Education (toim. Papadourakis, George)

Härkäpää, L. (2001). Kaupankäynnin vyöhyke yrityskäynnillä työssäoppimisen kehittämismahdollisuutena. Teoksessa Tuomi-Gröhn, T. \& Engerström, Y. (toim.) Koulun ja työn rajavyöhykkeellä. Yliopistopaino.

Johnson, A. \& Snaith, T. (1998). Project-based learning in leisure management training. Teoksessa Milter, R. G. \&Stinson, J. E. \& Gijselaers, W. H. (toim.) Educational innovations in economics and business III Innovative practices in Business Education. Dordrecht: Kluwer Academic Publishers.

Lonka, K. \& Hakkarainen, K.(2000). Oppiminen vuonna 2020. Psykologia 2/2000.

Miettinen, R. \&, Peisa, S., (2002). Integrating School-based Learning with the Study of Change in Working Life: the alternative enterprise method. Journal of Education and Work, Vol. 15, No 3, 2002.

Poikela, S. (2003).Ongelmaperustainen pedagogiikka ja tutorin osaaminen. Acta Universitatis Tamperensis A250. Tampere University Press.

Stehr, N. (1994). Knowledge societies. Sage Publications.

Tordtenddon, T. \& Menani, S. (2003). Problem Based learning from Teacher's Student's and Education Perspectives Teoksessa New Horizons in Industry and Education (toim.) Papadourakis, G. M.

Zaharia, S. \& Uebersfeld, J. \& Marinas, L. (2003). The Role of Knowledge Management in the Partnership between Universities and Enterprises Teoksessa New Horizons in Industry and Education (toim.) Papadourakis, G. M.

Vartiainen, M. (2000). Tutkivat oppijat. Aikuiskasvatus 2/2000.

Vesterinen, P. (2003). Projektiopiskelu ja -oppiminen ammattikorkeakoulussa Teoksessa Ammattikorkeakoulupedagogiikka, Edita 2003 (toim.) Kotila, Hannu. 
3. Hakkarainen ym. (1999) arvioivat, että opiskeli-

1. Asiaa tutkivat mallit voidaan jäsentää vaihe- ja ja, joka on tottunut oppimaan opettajajohtoisesti, saattaa kohdata vakavia vaikeuksia, kun opeaskelmalleihin sekä syklimalleihin. Katso esimerkiksi Poikela (2003, 137). Hänen mukaansa kyseisiä malleja ei ole juurikaan vertailtu keskenään tai eritelty niiden vaikutuksia käytäntöön.

2. Tordtenddon \& Menani (2003, 291) ovat Problem Based Learning (PBL) tutkimuksessaan päätyneet suosittamaan tutorialiryhmän kooksi 5-7 opiskelijaa. Tällöin ryhmä ei heidän mielestään ole liian pieni eikä liian suuri. tusmetodi vaihtuu vahvasti opiskelijalähtöiseksi. Tämäntyyyppinen tilanne voidaan kohdata erityisesti opiskelijaryhmässä, joka koostuu vaihto-opiskelijoista.

4. Tordtenddon \& Menani (2003, 291) määrittelevät Problem Based Learning -oppimistapaan liittyen, että ryhmät kokoontuvat kerran viikossa 90 minuutin ajan. Työelämälle toteutetussa kansainvälisessä tutkimushankkeessa ryhmän on kokoonnuttava silloin kun asia sitä vaatii. 